\title{
The Challenges of Population Aging
}

in the People's Republic of China

\section{中华人民共和国的人口老龄化挑战}



The Challenges of Population Aging in the People's Republic of China 中华人民共和国的人口老龄化挑战 
(c) 2021 Asian Development Bank

6 ADB Avenue, Mandaluyong City, 1550 Metro Manila, Philippines

Tel +632 8632 4444; Fax +63286362444

www.adb.org

Some rights reserved. Published in 2021.

ISBN 978-92-9262-972-4 (print); 978-92-9262-973-1 (electronic)

Publication Stock No. BRF210280-2

DOI: http://dx.doi.org/10.22617/BRF210280-2

The views expressed in this publication are those of the authors and do not necessarily reflect the views and policies of the Asian Development Bank (ADB) or its Board of Governors or the governments they represent.

ADB does not guarantee the accuracy of the data included in this publication and accepts no responsibility for any consequence of their use. The mention of specific companies or products of manufacturers does not imply that they are endorsed or recommended by ADB in preference to others of a similar nature that are not mentioned.

By making any designation of or reference to a particular territory or geographic area, or by using the term "country" in this document, ADB does not intend to make any judgments as to the legal or other status of any territory or area.

This work is available under the Creative Commons Attribution 3.0 IGO license (CC BY 3.0 IGO)

https://creativecommons.org/licenses/by/3.0/igo/. By using the content of this publication, you agree to be bound by the terms of this license. For attribution, translations, adaptations, and permissions, please read the provisions and terms of use at https://www.adb.org/terms-use\#openaccess.

This CC license does not apply to non-ADB copyright materials in this publication. If the material is attributed to another source, please contact the copyright owner or publisher of that source for permission to reproduce it.

$\mathrm{ADB}$ cannot be held liable for any claims that arise as a result of your use of the material.

Please contact pubsmarketing@adb.org if you have questions or comments with respect to content, or if you wish to obtain copyright permission for your intended use that does not fall within these terms, or for permission to use the ADB logo.

Corrigenda to ADB publications may be found at http://www.adb.org/publications/corrigenda.

Notes:

In this publication, "\$" refers to United States dollars and "CNY" to yuan.

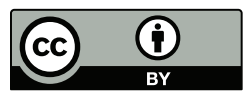

政府间组织3.0版知识共享许可协议（CC BY 3.0 IGO）

(C) 亚洲开发银行2021

位, 1550 Metro Manila, Philippines （菲律宾马尼拉）

4444; 传真 +63286362444

www.adb.org

部分版权所有。2021 年出版。

ISBN 978-92-9262-972-4 (印刷版); 978-92-9262-973-1 (电子版)

出版物库存号: BRF210280-2

DOI: http://dx.doi.org/10.22617/BRF210280-2

本出版物中所述为作者个人观点, 并不代表亚洲开发银行（亚行）、亚行理事会或其所代表的政府的观点和政策。

亚行不担保本出版物中所含数据的准确性, 而且对使用这些数据所产生的后果不承担任何责任。本出版物中提及特定公司或厂商产品并不意味着亚行认 为其优于未提及的类似性质的公司或厂商产品, 并予以认可或推荐。

在本出版物中指称或引用某个特定版图或地理区域时, 或使用 “国家”一词时, 不代表亚行意图对该版图或区域的法律地位或其他地位做出任何评判。

本出版物采用 “政府间组织3.0版知识共享许可协议” (CC BY 3.0 IGO) http://creativecommons.org/licenses/by/3.0/igo/。使用该出版物中的内容即 表示同意遵守上述许可协议的条款。有关署名、翻译、修改和权限的信息, 请参阅https://www.adb.org/terms-use\#openaccess中的规定和使用条款。

本知识共享许可不适用于本出版物中非亚行版权的资料。如某资料另有来源, 请联系该资料的版权所有人或出版人获得复制许可。亚行对因使用此类资 料所产生的任何索赔不承担责任。

如对本出版物内容有任何疑问或建议, 或希望就不适用于上述条款的预期用途获得版权许可, 或申请亚行标识的使用许可,

请联系pubsmarketing@adb.org。

亚行出版物勘误信息可在以下网页查询: http://www.adb.org/publications/corrigenda。

注: 在本出版物中, “\$”表示美元, “CNY”表示人民币。

译文声明

为扩大读者范围, 特将本出版物由英文翻译为中文。亚洲开发银行 (亚行) 尽力确保翻译的准确性, 但英语是亚行的官方语言, 因此, 本出版物的英文 原版是唯一合法的 (即官方的和经授权的) 文本。任何对本出版物内容的引用, 必须以其英文原版内容为准。 


\section{Abstract 摘要}

- Population aging increases pressure on the provision of health care services and the sustainability of pensions. It also creates labor shortages that, if unaddressed, can slow down economic growth.

人口老龄化加剧对提供医疗卫生服务和可持续养老金的压力。如果不加以解决, 还会导致劳动力 短缺, 从而减缓经济增长。

- While aging poses great challenges, if managed well, it can generate new employment opportunities with the emergence of new professions related to elderly care. However, capturing these benefits requires labor market reforms, higher public spending to finance long-term care and pensions, and policy support for the silver economy.

尽管老龄化问题带来巨大挑战, 如果管理得当, 可以借助老年护理新职业的兴起创造新的就业机 会。然而, 获取这些利益要求劳动力市场改革, 提高长期护理和养老金方面的公共支出, 并为银 发经济发展提供政策支持。

- This note aims to present policy recommendations to address selected socioeconomic implications of rapid population aging in the People's Republic of China (PRC) with a focus on labor market changes, effective long-term elderly care, and measures to address the increasing old-age dependency ratio.

此政策说明旨在提出相关政策建议, 重点关注劳动力市场变革、长期老年护理以及解决不断上升 的老年抚养比率, 帮助在中华人民共和国（中国）应对人口快速老龄化所产生的特定社会经济影 响。 


\section{观察与建议}

\section{INTRODUCTION}

1. The repercussions of population aging in an economy are greater than the better-known spiraling costs of pension and health care. Aging constrains economic growth as it results in labor force shortages. The population in the PRC is aging rapidly. The proportion of people aged 60 and above is expected to increase to $35 \%$ by 2050 -turning the population into one of the oldest in the world, at a very fast pace. The latest census data show that those aged 60 and above already account for $18.7 \%$ of the country's total population in 2020. This trend results from increased average life expectancy levels and declining fertility rates. ${ }^{1}$

2. The PRC's favorable demographics between 1975 and 2005 caused its total dependency ratio-defined as the share of children and older persons to the working-age population - to fall by about 50\%. The working-age population doubled from 400 million in 1978 to 800 million in 2005, generating a large demographic dividend that added about 2 percentage points per year to gross domestic product (GDP) growth. ${ }^{2}$ However, in 2016 the working-age population peaked at 1 billion, but has been declining since-creating labor force shortages that increase labor costs, undermining the country's production capacity and export competitiveness. The country is already losing competitive advantage in labor-intensive industries, but losses are not being compensated by an advantage in knowledge-intensive industries.

3. While aging poses great challenges, if managed well, it can generate new employment opportunities with the emergence of new professions related to elderly care. However, capturing these benefits require labor market reforms, higher public spending to finance long-term care and pensions, and policy support for the silver economy to form a needs-oriented economic system for the aging population. ${ }^{3}$ Based on international experiences, this note aims to present policy recommendations to address selected socioeconomic implications of rapid population aging in the PRC.

\section{POPULATION AGING AND THE LABOR MARKET}

4. Developed countries were the first to age. They approached the problem by shifting from inputdriven growth models - fueled by the accumulation of capital and labor-to productivity-driven models. ${ }^{4}$ However, the shift requires structural reforms to boost the contribution of technology and innovation to growth, which involves labor market flexibility and investments in human capital

1 In the PRC, the average life expectancy has increased from 44 years in 1950 to 77 years in 2021. In major cities like Beijing and Shanghai, the average life expectancy is over 80 years. Correspondingly, the fertility rate has declined sharply from 6 children per woman to 1.3 children during the same period.

2 ADB. 2014. Observations and Suggestions No. 2014-3. Challenges and Opportunities of Population Aging in the People's Republic of China. Manila.

3 Silver economy refers to the part of the economy related to production, consumption, and trade of goods and services relevant for older persons, both public and private.

4 ADB. 2014. Observations and Suggestions No. 2014-3. Challenges and Opportunities of Population Aging in the People's Republic of China. Manila. 
The Challenges of Population Aging in the People's Republic of China

中华人民共和国的人口老龄化挑战

to catch up with technological change. More specifically, new skills are needed to accommodate products and services to the health, travel, care, and recreational needs of older persons. These challenges can be translated into opportunities through improved labor mobility and training or retraining efforts. To address the challenge of aging, policy actions are needed to increase labor supply and productivity. The following policy recommendations are suggested:

(i) Enhance labor mobility. Mobility restrictions in the PRC - the household registration system (hukou) and the non-portability of social security benefits-discourage transfers from labor-surplus provinces to labor-deficit ones. These institutional barriers hinder natural migration flows and deter urbanization, resulting in an inefficient allocation of labor to sustain growth. Reallocating labor from low- to high-productivity sectors could add several percentage points to GDP growth. It is recommended to accelerate the ongoing relaxation of the hukou policy underpinned by social security reforms for migrant workers to gain access to social services and benefits in their place of residency.

(ii) Foster human capital: education. Investing in human capital is essential to increase labor mobility and productivity in the PRC. While the past decade has witnessed a substantial expansion in secondary and tertiary education in the PRC, gross enrollment rate in senior high schools and the percentage of population with tertiary education in scientific and technical subjects need to increase. The growing digitalization of the economy and the provision of more sophisticated services require changes in education policies. Learning methods should encourage lifelong learning, creativity, innovation, and problem-solving skills. Efforts should be complemented with incentives for firms to provide on-the-job training, and initiatives to retrain workers with obsolete skills to prolong their participation in the labor force. This would matter most in rural and less-developed areas, where improvements in human capital would be indispensable for future growth. In this regard, given the high propensity to drop out in main migrant-sending areas, subsidies could be provided for children to access early childhood education, as being an essential foundation for higher educational attainments, and to increase senior high school enrollment and completion, as being critical to meet the future demand for highly skilled labor. Reforms to improve quality and relevance of vocational and academic high school education could also foster human capital.

(iii) Foster human capital: health. Health-care services will also play a role in supporting the human capital needed to increase labor supply. Health services will need to be provided in such a manner as to maintain optimal health and function for older persons. Health, cognition, and vitality-not chronological age-are key for labor productivity and the ability to work of the older population. As life expectancy rises and educational attainment increases, the health of the older population will also rise, and older persons will need less care and be better able to work.

(iv) Encourage female participation in the labor market. Increasing female participation in the labor market will reduce labor shortages. While gender gaps in education have largely 


\section{观察与建议}

closed, female workforce participation has declined over the past decade to about $58 \%$ and is lower than that of men (76\%). Women in the PRC continue to bear a disproportionate responsibility for unpaid care work within the home and remain underrepresented in scientific research and high-technology industries and services. Women's participation in the labor force can be encouraged through the introduction of policies for equal employment opportunities; increased maternity leave; and improved support for childcare, elderly care, and single mothers.

(v) Open up to immigration. Welcoming workers from countries with younger populations is the most direct way to increase labor supply. This is best illustrated by experiences in Australia, some European countries, and the United States, where imported labor has contributed to address labor shortages and boost population growth. The PRC could consider opening up specific sectors of its labor market (i.e., high-tech industries, health care) to specialized workers to rapidly address talent shortages. Similarly, incentives could be developed to facilitate the return of Chinese nationals educated abroad.

\section{POPULATION AGING AND ELDERLY CARE}

5. Long-term care (LTC) systems in developed countries differ depending on the role of the state and the structure of the health and social protection systems. France, Germany, and the Netherlands rely on the social insurance system for LTC because functional dependency is seen as an area where society must be able to provide a pooling mechanism. In Scandinavian countries, LTC is financed through taxes and managed by public providers. Most countries have separate schemes for medical and social care as integrating LTC into the health-care system tends to lead to inefficiencies if LTC patients are treated in general hospitals at a higher cost. ${ }^{6}$ Since its 12 th Five-Year Plan, the PRC has promoted the establishment of an integrated health and three-tiered elderly care system (residential, home, community) and strengthened involvement of the private sector in investing in elderly care services. However, progress has been slow and both supply and utilization of services have been limited.

6. Public social safety nets for older persons and LTC services are at the early stages of development in the PRC. In rural areas, where a majority of older persons reside, the needs are more acute, low pensions result in family members being the primary source of support for $85 \%$ of older persons. However, the support mechanism provided by family members is put at risk by the socioeconomic changes brought about by economic development, modern lifestyle, and low fertility rates. For this, developing an efficient LTC is a priority that requires different models considering the socioeconomic variations within the PRC. The following policy recommendations are proposed:

5 X. Dong and V. Mendizabal Joffre. 2019. Inclusive Growth in the People's Republic of China: A Deep Look at Men's and Women's Work amid Demographic, Technological, and Structural Transformations. ADB East Asia Working Paper Series. No. 23. Manila: ADB. 
The Challenges of Population Aging in the People's Republic of China

中华人民共和国的人口老龄化挑战

(i) Strengthen the three-tiered elderly care system for the provision of LTC. The lack of affordable elderly care facilities results in unnecessary admissions in acute care hospitals and a waste of health-care resources. Improved home- and community-based LTC can address this as shown in Denmark, where this approach has released 30\% of hospital beds. Greater and the correct incentives (financial, regulations) to develop home and communitybased services, such as home help, home care, and home-nursing services, and centerbased services to support older persons, are required to meet the "90-7-3 older persons care pattern" from the 12th Five-Year Plan (90\% of the older persons should receive home-based care, $7 \%$ community-based care, and 3\% residential care). Development of preventive health-care services to older persons at community level to defer the need to use LTC should also be prioritized.

(ii) Increase LTC financing. Larger-scale resources are needed to develop elderly care in the PRC. Public health-care expenditure in the country stands at $2.9 \%$ of GDP compared with a 6.5\% average in Organisation for Economic Co-operation and Development (OECD) countries, where LTC alone amounts to $1.7 \%$ of GDP. The increased financial needs should not threaten fiscal sustainability. A more progressive taxation system, further liberalization of energy and resource prices, the introduction of environmental and property taxes, and the transfer of a larger share of dividends of state-owned enterprises into public expenditure will allow increases in social spending without straining public finances.

(iii) Expand health insurance for financial protection. The PRC has made significant progress in extending health insurance coverage universally, but out-of-pocket payments still account for about $50 \%$ of total health expenditure, exacerbating the vulnerability of lower-income households. It is recommended to further expand the health insurance coverage, reduce co-insurance rates, and introduce ceilings on maximum out-of-pocket payments, including programs to address the needs of the most vulnerable groups. This approach could pave the way for the introduction of LTC insurance in the future, coupled with increased pension benefits to ensure the ability of the elderly to pay for it.

(iv) Promote private sector participation. While elderly care facilities catering for the well-off are proliferating, there is an urgent need to increase affordable elderly residential care for those who need assistance and have limited means to pay. In other countries, such facilities are usually financed by a mix of government support, individual pension contributions, and private sector involvement. In OECD countries, state-owned facilities are often privately managed, with private sector participation incentivized through tax relief or subsidies. This approach is also emerging in the PRC and needs to be strengthened and mainstreamed. It is recommended that the role of the PRC's government in the provision of LTC shifts from supplier to regulator for setting policies and standards, and to purchaser for subsidizing not only the poorest section of the population but also the middle class who cannot afford the 


\section{观察与建议}

private facilities. Developing effective models of public-private partnership (PPP) is key to support these efforts. ${ }^{7}$

(v) Develop a professionalized elderly care workforce. Human resources, incentives, and policies to retain and train LTC givers are insufficient in the PRC. Many other professions crucial to a well-functioning elderly care system, including nurses; allied health professionals (i.e., physiotherapists, occupational therapists, nutritionists); medical specialists (i.e., geriatric physicians, neurologists); social workers; service providers; and managers are also lacking. It is urgent to address the shortage of human resources and raise its quality by improving staff retention incentives and prioritizing training and skills development initiatives for the caregivers. In addition, the availability of professionals in paramedical, medical, social work, and elderly care management has to increase to fill the skill gaps in the sector. This will in turn generate new employment opportunities.

\section{POPULATION AGING AND OLD-AGE DEPENDENCY RATIO}

7. A low old-age dependency ratio and a large demographic dividend underpinned the PRC's unprecedented socioeconomic transformation since 1978. However, both trends are now reversed. The old-age dependency ratio has increased to 16\% in 2019 and the demographic dividend vanished in 2016. While figures are not yet alarming, the speed of aging and its implications on the sustainability of growth and the pension system demand new actions. Suggestions are as follows:

(i) Continue fine-tuning family policies. At 1.3 children per woman, and at 0.7 children per woman in cities like Shanghai, the current fertility rate is below the replacement rate (2.1). The relaxation of the one-child and two-child policies can ease the burden of onlychildren caring for elderly parents and grandparents-the so-called "4-2-1" problem-but needs supplementary policy actions. These could include more affordable social services, higher pensions, and support to women through subsidies for childcare, baby bonuses, child grants, education support, flexible hours or part-time work, and other measures as detailed in paragraph 8. Developing family-friendly cities and communities will also be important to support families with children.

(ii) Accelerate the increase in retirement age. As a result of dramatic longevity improvements, developed countries have continuously revised retirement age by increasing it to 65-67 years. As a result, in addition to increasing the labor supply, prolonging labor market participation supported the sustainability of the pension systems and was crucial for the success of a multigenerational workforce. In the PRC, the retirement age was established in 1950 at 60 for men and at 55 and 50 for women in white- and blue-collar jobs, respectively. Since then, it has not been revised. Under the current average life

$7 \quad$ ADB is piloting PPPs in elderly care services through investment projects with PPP components in various locations in Hubei province and Guangxi Zhuang Autonomous Region. 
expectancy ( 75 for men and 79 for women), plans to gradually increase the retirement age should be accelerated and women's retirement age should be aligned with that of men to eliminate gender disparities. During the transition, schemes for voluntary retirement at an older age to allow people to continue to work, if they can or want to, could be piloted to draw lessons for the rollout of the program nationwide at a later stage. These schemes, however, need to be complemented with age-friendly policies such as providing more flexible work options; promoting lifelong learning (i.e., retraining, reskilling); and creating age-friendly workplaces, including incentives for employers to hire older workers.

(iii) Accelerate pension reform. The low coverage, structural, and financial weaknesses of the current pension scheme demand further reform. It is recommended to step up current plans to establish a three-pillar system, with the pillars complementing each other and providing the best possible financial security. The first pillar would be a defined-benefit basic flat rate pension, financed by taxes and fiscal transfers, supported by the national pension reserve fund. The second pillar, a mandatory defined-contribution scheme funded by individual accounts, already exists in the PRC; it needs to be strengthened to generate sufficient returns for the expected replacement rates. The third pillar-voluntary private pension funds, for which a first pilot was launched in June 2021 in East Zhejiang province and in a municipality of Chongqing-needs to progress faster. Further, while accelerating pension reforms, the incorporation of automatic adjustment mechanisms to link retirement age to life expectancy, so it rises as the length of life increases, and financial liberalization for the successful establishment of private pension funds should be considered. A larger variety of investment options and a less restrictive regulatory framework are needed to strengthen the individual accounts. 


\section{观察与建议}

\section{一、引言}

1. 在经济体中, 比起更广为人知的螺旋式上升的养老金和医疗费用, 人口老龄化的影响更为广 泛, 它会导致劳动力短缺, 从而限制经济增长。中华人民共和国 (中国) 的人口正经历迅速老龄 化。预计到2050年, 中国60岁及以上人口的比例将增至35\%, 快速迈入世界上人口老龄化最严重 的国家之一。最新人口普查数据显示, 2020 年 60 岁及 60 岁以上人口已占该国总人口的 $18.7 \%$ 。这一 趋势是由于平均预期寿命上升和生育率下降所致。

2. 1975一-2005年间, 由于中国的人口结构优化, 总抚养比（即儿童和老年人占劳动年龄人口的比 例）下降了约 $50 \%$ 。这种情况产生了巨大的人口红利, 劳动年龄人口翻了一番, 从1978年的4亿增 至2005年的8亿, 每年贡献大约两个百分点的国内生产总值 (GDP) 增长。 ${ }^{2}$ 然而, 劳动年龄人口 在2016年达到10亿峰值后, 一直呈下降趋势, 导致劳动力短缺, 增加了劳动力成本, 从而削弱了 国家的产能和出口竞争力。中国失去了在劳动密集型产业中的竞争优势, 但其损失并未因知识密 集型产业的优势得到补偿。

3. 尽管老龄化带来了巨大的挑战, 但如果管理得当, 老年护理新职业的兴起会带来新的就业机 会。然而, 为使上述益处变为现实, 需要进行劳动力市场改革, 提高长期护理和养老金方面的公 共支出, 并为银发经济发展提供政策支持, 帮助建立人口老龄化需求导向经济体系。 ${ }^{3}$ 本政策说明 基于相关的国际经验, 提出了一些政策建议, 为帮助中国应对人口快速老龄化所产生的特定社会 经济影响。

\section{二、人口老龄化和劳动力市场}

4. 人口老龄化最先发生在发达国家。为解决这一问题, 他们由投入驱动的增长模式 (由资本和 劳动力的累积所推动) 转变为由生产力驱动的增长模式。 ${ }^{4}$ 然而, 该类转变需要通过结构性改革 来促进技术和创新对增长的贡献, 为此, 就需要提高劳动力市场的灵活性、增加人力资本投资, 以推动技术变革。具体而言, 需要发展新技能来为老年人提供产品和服务, 满足他们的健康、旅 行、护理和娱乐需求。可通过提高劳动力流动性以及加强培训或再培训, 将这些挑战转变为机 遇。要应对老龄化挑战, 就需要采取政策行动来增加劳动力供给并提高生产力。为此, 我们提出 了以下政策建议:

（1）增强劳动力流动性。中国的流动性限制, 包括户籍制度（户口）和社会福利的 “不可携 带性”, 阻碍了从劳动力过剩省份向劳动力短缺省份的转移。这些制度阻碍了自然迁移

1 在中国, 平均预期寿命从1950年的44岁上升到了现在的77岁。北京、上海等大城市的平均预期寿命更是超过80岁。 同期人均生育率也相应地从每名女性6名急剧下降到1.3名。

2 亚行, 2014, 《观察与建议》第2014-3期, 《中华人民共和国的人口老龄化挑战与机遇》, 马尼拉。

3 银发经济是指与老年人相关的商品和服务的生产、消费和贸易相关经济部分, 包括公共和私营部门。

4 亚行, 2014, 《观察与建议》第2014-3期, 《中华人民共和国的人口老龄化挑战与机遇》, 马尼拉。 
The Challenges of Population Aging in the People's Republic of China

中华人民共和国的人口老龄化挑战

和城市化, 导致劳动力配置效率低下, 不利于经济持续增长。从低生产力部门到高生产 力部门的劳动力再分配可使GDP增加若干百分点。建议在实施外来务工人员社保改革的 基础上，持续放宽户籍政策，以便外来务工人员在居住地获得社会服务和福利。

（2）提升人力资本：教育。人力资本投资对于提高中国的劳动力流动性和生产力至关重要。 过去十年, 中国的中等和高等教育规模大幅扩张, 但高中毛入学率和科技类高等教育人 口比重有待提高。为促进经济数字化和提供更复杂的服务, 需要进行教育政策改革。应 采用有助于促进终身学习和提高创造力、创新和问题解决能力的学习方法。其他补充措 施包括鼓励企业提供在职培训, 对技能已过时的工人进行再培训, 以延长他们的劳动参 与度。这对于农村和欠发达地区最为重要, 因为在这些地区, 人力资本的改善对于未来 的增长必不可少。在这方面, 考虑到主要劳动力输出地区的辍学倾向较高, 可以为儿童 提供早期教育补贴, 为他们获得高等教育奠定重要基础, 并提高高中入学率和毕业率, 作为满足未来对高技能劳动力需求的关键一环。通过改革提升职高和普高教育的质量与 相关性有助于培育人力资本。

（3）培育人力资本：健康。医疗健康服务将在支持增加劳动力供应所需的人力资本方面发挥 作用。需要通过提供医疗健康服务来帮助老年人维持最佳健康状况和身体机能。劳动生 产率和老年人口工作能力取决于健康、认知和活力状况, 而非实际年龄。随着预期寿命 延长和教育程度提高, 老年人口的健康状况将得到改善, 所需的照护减少, 工作能力增 强。

（4）鼓励女性在劳动力市场的参与度。促进女性参与劳动力市场将帮助解决劳动力短缺问 题。虽然教育的性别差距已基本缩小，但过去十年女性劳动力参与率降至约 $58 \%$, 低于 男性的 $76 \%$ 。 ${ }^{5}$ 中国的女性继续承担更多家庭内的无偿照料工作，在科学研究、高技术 产业和服务业中所占的比例较低。可通过出台增加平等就业机会, 延长产假以及加大对 育儿、养老和单身母亲的支持政策来促进女性参与劳动力市场。

（5） 开放劳工移民。增加劳动力供应的最直接方式是欢迎来自人口年轻国家的劳动者。澳大 利亚、欧洲国家和美国的经验就是典范，这些国家通过引进劳动力解决了劳动力短缺问 题并促进了人口增长。为迅速解决人才短缺问题, 中国可考虑吸收专业工人进入劳动力 市场的特定部门（即高科技产业、医疗健康）。同样地，还可通过制定激励措施，为在 国外接受教育的中国公民回国提供便利。

5 X. Dong和V. Mendizabal Joffre, 2019, 《中华人民共和国包容性增长: 深入研究中国男性和女性在人口结构、技 术和结构性转型中的工作》，东亚局系列工作论文，第23期，马尼拉：亚行。 


\section{观察与建议}

\section{三、人口老龄化和养老服务}

5. 发达国家长期护理（LTC）体系的差异取决于其国家角色及其卫生和社保体系。法国、德国 和荷兰依赖于LTC的社保体系, 因为人们认为社会必须提供统筹机制来满足功能依赖性。在斯堪 的纳维亚国家, LTC的资金来自于税收, 由公共供应商管理。如果LTC患者在综合医院的治疗成 本增加, 那么将LTC纳入医保体系往往会导致效率低下。为此, 大多数国家均制定了独立的医疗 及社会护理计划。6 “十二五” 以来, 中国推动建立了综合医疗健康和居民、家庭、社区三级养老 体系, 鼓励更多私营部门参与养老服务投资。然而, 该方面的进展缓慢, 服务供应和利用率均有 限。

6. 中国面向老年人的公共社会安全网和长期护理服务刚刚起步。在农村地区, 老年人口占大多 数, 需求也更为迫切, 但由于养老金较低, 有 $85 \%$ 的老年人主要由家庭成员照料。然而, 经济发 展、现代生活方式和低生育率使社会经济发生变化, 导致由家庭成员提供支持的机制面临诸多风 险。为此, 中国迫切需要一个不同的模型来考虑不同社会经济变量从而建立高效的LTC体系。我 们提出了以下政策建议:

（1）强化三级养老体系, 提供长期护理服务。由于缺乏老年人负担得起的养老机构, 急诊医 院中不必要的入院增加, 造成了医疗资源浪费。改善家庭和社区长期养老护理有助于解 决这一问题, 例如丹麦就通过这一方法释放了 $30 \%$ 的病床。要发展家庭帮助、家庭护理 和居家护理等家庭和社区养老服务, 就需要出台更多适当的激励措施（财政、法规）, 还要为老年人提供养老中心服务支持, 以发展 “十二五” 规划提出的90+7+3中国式养老 模式（即 $90 \%$ 的中国老人为居家养老，7\%是社区养老，3\%是机构养老）。此外, 还应 优先考虑在社区层面为老年人提供预防保健服务, 以推迟使用LTC服务的需求。

（2）扩大LTC融资。在中国, 发展养老服务需要投入更多资源。中国的公共卫生支出占GDP 的比重为 $2.9 \%$, 而经济合作与发展组织（经合组织）国家的这一数据为 $6.5 \%$, 仅LTC就 占GDP的 $1.7 \%$ 。金融需求增加不应威胁到财政可持续性。可以推进累进税制、进一步放 开能源和资源价格、引入环境税和财产税, 以及将更多的国有企业红利转为公共支出, 这些举措有助于增加社会支出, 又不会造成公共财政压力。

（3）扩大医保以增强财务保障。中国在扩大医保覆盖面方面取得了重大进展, 但自付医疗费 用仍占医疗总支出的 $50 \%$ 左右, 这加剧了低收入家庭的脆弱性。建议进一步扩大医保覆 盖面, 降低共同保险费率, 并设置自付费用上限, 包括制定满足最弱势群体需求的方 案。这种做法可为在未来引入长期护理保险奠定基础, 同时增加养老金福利以确保提高 老年人的支付能力。

（4）促进私营部门参与。面向富裕人群的养老机构不断涌现, 与此同时, 那些需要援助和支 付能力有限的老人也迫切需要负担得起的机构养老服务。在其他国家, 这些设施的资金 
The Challenges of Population Aging in the People's Republic of China

中华人民共和国的人口老龄化挑战

通常来自政府支持和个人养老金缴款以及私营部门参与。经合组织国家的国有设施通常 由私营部门进行管理, 通过税收减免或补贴等激励措施来促进私营部门参与。这种方法 在中国也日益兴起, 但还需进一步加强和实现主流化。建议中国政府在提供LTC时, 从 供应商的角色转变为制定政策和标准的监管机构, 以及为赤贫人口和难以负担私营部门 设施的中产阶级提供补助的采购方。开发有效的公共一私营部门合作 (PPP) 模式是支 持上述工作的关键。

（5）培养专业化养老人才队伍。中国用于留住和培训长期护理提供者的人力资源、激励措施 和政策不足。此外, 中国还缺乏对建立完善的养老体系至关重要的其他职业, 包括护 士、专职健康专家 (即物理治疗师、职业治疗师和营养师)、医学专家 (即老年科医 生、神经病学家）、社会工作者、服务提供者和管理人员。迫切需要增加员工留任激励 措施、优先制定针对护理人员的培训和技能发展措施, 以解决养老方面的人力资源短缺 问题并提高其质量。此外, 为弥合该领域的技能差距, 必须增加辅助医疗、医疗、社会 工作和养老管理专业人员。这反过来又会产生新的就业机会。

\section{四、人口老龄化和老年抚养比}

7. 较低的老年抚养比和巨大的人口红利为中国自1978年以来前所未有的社会经济变革提供了 支撑。然而, 目前这两种趋势都发生了逆转。2016年人口红利消失, 2019年老年抚养比率上升至 $16 \%$ 。虽然数据还没达到令人担忧的程度, 但仍需采取新行动, 来解决人口快速老龄化及其对增 长可持续性及养老金制度的影响。我们提出了以下建议:

（1）继续推进家庭政策微调。每名女性生育1.3个孩子, 上海等城市为 0.7 个, 当前生育率低于 人口替代率 (2.1)。通过开放一孩二孩政策, 可减轻独生子女照顾年迈父母和祖父母的 负担, 解决所谓的 “4+2+1” 问题, 但需要辅以政策行动, 可能包括提供更多可负担得 起的社会服务、增加养老金，并通过育儿补贴、生育奖励、儿童补助金、教育支持、弹 性工作时间或兼职工作以及第八段中详述的其他措施为女性发展提供支持。促进家庭友 好型城市和社区发展对于支持有孩子的家庭也非常重要。

（2）加快提高退休年龄。由于人均寿命显著延长, 发达国家在不断调整退休年龄, 最高达 到 65 67岁。因此, 除了增加劳动力供应外, 延长劳动力市场参与将提高养老金制度的 可持续性, 而且对形成多代劳动力结构的成功也很关键。中国自1950年设定退休年龄以 来，一直未对其进行过调整，其中从事白领和蓝领工作的男性退休年龄为60岁和55岁， 女性退休年龄为55岁和50岁。在目前的平均预期寿命 (男性75岁, 女性79岁) 下, 应加 快制定逐步提高退休年龄的计划，使女性退休年龄与男性保持一致，以消除性别差异。 在过渡时期, 可开展老年人自愿退休计划试点, 允许他们在可以或愿意的情况下继续工 作, 以总结经验教训, 方便未来在全国范围内推广该计划。但是这些计划需要辅以关爱

7 亚行正在湖北省和广西壮族自治区的不同地点投资包含PPP成分的项目，开展养老服务公私合作试点。 
老年人的政策, 例如提供更灵活的工作选择、促进终身学习（即再培训、技能再培训） 和创建适老工作场所, 包括为雇用老年工人的雇主提供激励。

（3）加快养老制度改革。需要针对当前养老保险制度的低覆盖率以及结构和财务上的不足, 进一步开展改革。建议强化现有规划, 建立包含三大支柱的体系, 这些支柱相辅相成, 可提供最佳资金保障。第一个支柱为有固定收益的基本统一养老费率, 由税收和财政转 移支付以及国家养老金储备基金提供支持。第二个支柱是由个人账户出资的强制性固定 缴纳计划, 该计划在中国已经存在, 但仍需进一步加强, 以产生足够的回报来实现预期 替代率。第三个支柱为自愿性个人养老金, 这一制度于2021年6月在浙江东部和重庆市首 次进行试点, 需要加快推进。此外, 在加快养老金改革的同时, 还应考虑引入可将退休 年龄和预期寿命挂钩的自动调整机制, 以便随寿命的提高调整退休年龄, 并应考虑放松 金融管制, 推动建立个人养老基金。为加强个人账户, 需提供更多投资选择, 并放宽监 管框架。 



\title{
The Challenges of Population Aging in the People's Republic of China
}

The population in the People's Republic of China (PRC) is aging rapidly, as the proportion of people aged 60 and above is expected to increase to $35 \%$ by 2050 . While aging poses economic challenges, if managed well, it can generate new employment opportunities with the emergence of new professions related to elderly care. However, capturing these benefits requires labor market reforms, higher public spending to finance longterm care and pensions, and policy support. This note presents policy recommendations to address identified socioeconomic implications of rapid population aging in the PRC, focusing on labor market changes, effective long-term elderly care, and measures to address the increasing old-age dependency ratio.

\section{About the Asian Development Bank}

ADB is committed to achieving a prosperous, inclusive, resilient, and sustainable Asia and the Pacific, while sustaining its efforts to eradicate extreme poverty. Established in 1966, it is owned by 68 members49 from the region. Its main instruments for helping its developing member countries are policy dialogue, loans, equity investments, guarantees, grants, and technical assistance.

\section{中华人民共和国的人口老龄化挑战}

中华人民共和国 (中国) 的人口正经历迅速老龄化, 预计到2050年, 中国60岁以上人口的比例将增至 $35 \%$ 。尽管老龄化带来了经济挑战, 如果管理得当, 可以借助老年护理新职业的兴起创造新的就业机会。 然而, 获取这些利益要求劳动力市场改革, 提高长期护理和养老金方面的公共支出, 并提供政策支持。此 政策说明旨在提出相关政策建议, 重点关注劳动力市场变革、长期高效的老年护理以及解决不断上升的老 年抚养比问题，帮助中国应对人口快速老龄化所产生的特定社会经济影响。

\section{关于亚洲开发银行}

亚行在坚持消除极端贫困的同时, 致力于实现繁荣、包容、有适应力和可持续的亚太地区。亚行成立于 1966年, 现有68个成员, 其中49个来自亚太地区。亚行主要通过政策对话、贷款、股权投资、担保、赠 款以及技术援助等工具向发展中成员体提供帮助。

$\mathrm{ADB}$

\section{ASIAN DEVELOPMENT BANK}

6 ADB Avenue, Mandaluyong City 1550 Metro Manila, Philippines www.adb.org

\author{
亚洲开发银行驻中国代表处 \\ 北京朝阳区建国门外大街1号 \\ 国贸大厦A座17层 \\ 邮编: 100004 \\ www.adb.org/prc \\ cn.adb.org
}

